\title{
Students Attitudes toward Blended Learning among students of the University of Jordan
}

\author{
Fatima Aladwan ${ }^{1}$, Hussam N. Fakhouri ${ }^{2}$, Abedalsalam Alawamrah ${ }^{1} \&$ Osama Rababah $^{2}$ \\ ${ }^{1}$ School of Educational Sciences, The University of Jordan, Amman, Jordan \\ ${ }^{2}$ King Abdullah II School of Information Technology, The University of Jordan, Amman, Jordan \\ Correspondence: Hussam N. Fakhouri, King Abdullah II School of Information Technology, The University of \\ Jordan, Amman, Jordan. E-mail: h.fakhouri@ju.edu.jo
}

Received: February 8, 2018 Accepted: November 16, $2018 \quad$ Online Published: November 26, 2018

doi:10.5539/mas.v12n12p217 URL: https://doi.org/10.5539/mas.v12n12p217

\begin{abstract}
Information and communication Technology and the use of internet has added many values to the educational process. Many approaches has been developed for this purpose including e-learning, distant learning and recently blended learning. Many universities are adopting these approaches for teaching students. Therefore this research aims to examine attitudes of University of Jordan students toward blended learning. A sample of 250 students were selected to complete online questionnaire who have taken blended coursest hat contains aspects of knowledge about and attitude toward blended learning and a high level of preferring toward blended learning. The results of the study indicated that blended learning is useful to Students, and that most students fully understand the goals of e-learning through blended learning. In general the students have shown positive attitude towered blended learning. Furthermore, they have shown adequate information about the field of blended learning and to decide when and how to use the resources provided to them through blended learning. it also indicated that blended learning is more effective than traditional way of teaching to develop and improve the knowledge and skills. The results also indicated that electronic resources provide through blended learning is an effective way that help students to get knowledge and improve their skills, and it has tremendous effect on students life to take responsibility for their own learning process.
\end{abstract}

Keywords: e-learning, blended learning, informational technology, electronic platform, higher education, questioning, attitude, assessment, efficiency, English

\section{Introduction}

Information and communication technologies are the processes, methods of searching, collecting, storing, and processing, providing, distributing information. The use of information and communication technologies (ICT) in the field of Education clearly has positive effects on the learning process. Developments in the information age have had impacts on education as well as on most of the fields. This impact has resulted in the formation of new paradigms in the education-learning process. Some of these paradigms is electronic learning (e-learning) distance learning and Blended learning (Yurdugul\&Alsancak-Sirakaya,2013) these educational paradigms has been evolved to use the ICT.

The first generation of e-learning or Web-based learning programs focused on presenting physical classroom-based instructional content over the Internet. In the second wave of e-learning, various delivery modes are combined into e-learning which is termed as the "blended learning". Many higher learning institutions in Jordan implemented elearning because of its effectiveness as an alternative learning approach. Currently, universities in Jordan are moving from e-learning into blended learning (ex. The university of Jordan has adapted many courses in blended learning)

Today, blended learning is one of the most important ways of the educational process. Its advantages are due to the fact that it combines traditional and online learning.

Problem-based learning (PBL), often incorporated in the blended learning strategy, is amethod in which a problem serves as the motivation for active learning. The PBL approach is student-oriented approach. Students define the problem and determine learning objectives in order to find a solution to the problem. This approach is based on small groups of students collaborating with each other and the teachers to achieve understanding (Berkson 1993; 
Fincham \& Shuler, 2001).

Blended learning is an educational approach that combines learning with the participation of a teacher (face to face) and online learning. Blended learning involves the elements of self-control by the student of the educational route, time, place and pace of learning, as well as the integration of learning experience with the teacher and online. In the blended learning process, online learning and teacher-related learning are equally important. The online environment provides students with the opportunity to control the pace, time, place and path of learning. It helps develop planning skills, self-control and self-regulation, and also gives freedom. Teaching with the teacher is an important part of blended learning. The role of the teacher varies according to the needs of the students. Pupils of elementary grades need almost constant presence of a teacher in a class. The teacher demonstrates patterns of behavior and thinking, ways of building relationships. Teenagers, students and adults need more likely a tutor, adviser, and specialist.

Integration of online learning experience with a teacher is an active form of work in the classroom. Such activities should be practice oriented. The most convenient format for conducting them is in small groups (work on projects, board games, etc.). Collective and individual work on projects is also possible.

There are more than 40 models of blended learning, but not all of them are equally effective. Some of the most important method is described here

\subsection{Models of Blended Learning}

\subsubsection{Inverted Class}

The easiest to implement model, It allows you to minimize frontal work (the teacher explains, the children listen) and allows you to implement interactive forms of work in the classroom.

Students work at home in an online learning environment, using their own electronic devices connected to the Internet: get acquainted with the material or repeat what they have learned. The class consolidates the material and works with it, which can take place in the form of project activities, a seminar or in other interactive forms. This model of blended learning can be applied in school for students from grade 3-5.

\subsubsection{Station Rotation}

The most effective blended learning model in primary and secondary schools. Requires the presence of computers or tablets in the classroom and the use of learning management systems

All students are divided into groups by type of educational activity: work with a teacher, online training and project work. Each group works in a separate part of the class - the station. Stations have different goals: working with a teacher - getting feedback from the teacher; online training - the development of skills of independent work, personal responsibility, self-regulation, ability to learn; project work - the application of knowledge in solving practical problems, the development of communication skills and receiving feedback from classmates.

During the lesson, students move from station to station so as to visit each of them. The composition of groups varies from one lesson to another according to the pedagogical task [2] .

Instead of three stations, two can be organized: work with a teacher and online work; or four: work with a teacher, online work, work on a collective project and individual independent work.

\subsubsection{Laboratory Rotation}

The "Rotation of Laboratories" blended learning model assumes that part of the student's classes take place in a regular class, and for one lesson they are transferred to a computer class (laboratory), where they individually work in an online environment. In the online environment, students can learn new material, consolidate their experience, train various skills and also work on their own project. If this model is implemented in school, then the most effective learning becomes when teachers create an online space for children that is common across several subjects. This blended learning model is suitable for students of any age, provided that the online environment is adequate for their age.

\subsubsection{Flexible model}

The basis of a flexible blended learning model is that students are not limited in time to one or another type of learning activity. Students independently draw up a work schedule; choose a topic and the pace at which they will study the material. This model mostly uses an online environment. The teacher works with small groups or individually with students who need help [3].

This model is most effective for teaching high school students, students and adults, as it requires a developed skill of self-organization. 


\subsection{Advantages and Disadvantages of Blended Learning}

Blended learning combines the advantages of distance and traditional teaching methods and has many advantages:

Face-to-face training enables interaction between students and the teacher, as well as students. In the process of joint study, a favorable educational environment is created, the mood to achieve results, the motivation to study. Participants in the learning process instantly receive feedback, discuss the material, and ask questions.

Cooperative learning and student interaction not only increases cognitive abilities, but also develops students' emotional intelligence.

From the point of view of online learning, a mixed model provides more freedom for students: they can choose the material, pace, time and place of study.

The teacher has more freedom in presenting teaching materials, monitoring and evaluation. Reduced time to test performance, due to the fact that testing can be done online. This necessitates a study in Jordan context to investigate the current level of adoption of blended learning among the students, and identify the factors influencing the adoption of blended learning. We conducted this study to determine the relationship of students to blended learning, measuring the impressions of its use and the identification of the views prevailing in students about blended and e-learning.

\section{Related Work}

Many researchers studied the effectiveness of blended learning. in particular, it has been found that blended learning basically responds to educational to the needs of students, delivering them satisfaction, shaping and perfecting the linguistic skills as well as developing critical thinking skills.

Ahmad (2008) has shown that students demonstrate positive perceptions towards blended learning. Therefore, with the help of technology, blended learning can be used as an alternative approach in teaching and learning mathematics in order to motivate students. It is recommended that the courseware to be made available online and to carry out further study on a larger scale to confirm the positive results.

A study by Ünsal (2007) which mainly aimed to compare the effectiveness of blended and face-to-face learning environments in terms of student achievement and motivation examined the course designed for the study with the dimensions of reaction, achievement and behavior assessment. Robison's (2004) study investigated the experiences of ten faculty members in designing and teaching blended learning courses at Brigham Young University. The results of the study revealed that the participant faculty members perceived three major benefits in the blended learning experience. Coynea (2018) conducted a study which incorporates video-assisted online resources, may be a useful tool to teach clinical skills to students of health including nursing. Blended learning not only increases students' knowledge and skills, but is often preferred by students due to its flexibility. Ersoy (2003) carried out a study with 65 undergraduate students enrolled in the course named "Programming Languages II" in order to demonstrate the contributions of web-based instruction to traditional face-to-face instruction. The course was taught using the traditional face-to-face instruction method and was supplemented by a web site. The quantitative data showed that the students' perceptions about web-based instruction and online instructor were positive, but online collaborative learning perceptions are about neutral. Beside the research questions, some design considerations in the blended learning case were presented.

Hien (2017), the finding confirms that BL is significantly associated with greater learning performance of STEMdisciplined students than with traditional classroom practice. Accordingly, discussion concerning the findings and implications for future research are elaborated. However, the results indicate that courses in STEM subject matters display a higher average effect size than non-STEM ones. Interestingly, subject matter was found to exert a moderating effect in Schmid et al. (2014) when levels of technology use were used to sub-divide the control condition, i.e. no technology and some technology use. Graham (2006) posits that as a combination of traditional face to face instruction and online learning, BL allows for more interactive and reflective knowledge construction. Multi-format resources, archived discussions, instructors' changing role as facilitators, and more time and scaffolding for discussion and reflection in this learning mode have been augmented by technologies (Mebane, Porcelli, Iannone, Attanasio, \&Francescato, 2008).

SezenTosuna (2015)study results discovered many advantages of blended learning instruction over face-to-face instruction. On the contrary to many other studies, students did not achieve great learning outcomes by the end of 6-weeks blended instruction program. The results of the research might be attributed to the short duration of the study. Results indicated that the proposed blended learning strategy did not improve the students' vocabulary achievement. Although students were satisfied with the proposed blended learning strategy in teaching vocabulary and prefer it to the traditional classroom based learning, they did not want to spend time studying new vocabulary 
items outside the classroom due to their lack of motivation. Since the students in this particular study do not have the self-discipline to make e-learning a powerful option which allows them to work independently at their own pace, it is highly recommended that curiosity and authenticity should be provoked by different types of online tools.

Blended learning may be used in any field of teaching for example recent studies have proven many benefits of different technology-based instructional materials for effective verbal and written communication (Schmidt \&Hegelheimer, 2004; Pazio, 2010; Khazaei \& Dastjerdi, 2011). Another example of using BL in nursing teaching; Shorey (2018)conducted a study that show that BL used in redesigning the communication module for nursing undergraduates which was successful in enhancing their satisfaction levels and self-efficacies. The students had positive attitudes towards learning communication skills. The students scored significantly higher on the Blended Learning Satisfaction Scale, the Communication Skills Attitude Scale, and the communication skills subscale of the Nursing Students Self-Efficacy Scale. Another example of using blended learning in finance courses; F. Alshehri (2017) It is the first study to explore the levels of satisfaction and commitment of students enrolled on finance courses using an IM. Through the analysis of a sample of 100 undergraduate students enrolled on a blended learning finance course at King Khalid University, Saudi Arabia in the academic year 2012, the study proved the validity of such an IM in predicting the levels of satisfaction and commitment of students. It was found that the levels of student satisfaction and commitment with the finance course were in the middle of the possible range. Specifically, the results showed that there was a significant negative correlation between student satisfaction and the GPA scores of the students concerned, but a significant positive correlation between student commitment and GPA score.

Harona, reported the adoption of blended learning among academicians in Malaysia. The Findings in his study identifiedthat the adoption rate of blended learning is low, as reflected from the result of the study where only 13 percent of the academicians adopted the learning approach. Among the factors which influenced the adoptionof blended learning are perceived usefulness of the system, learning goals, and educational technology preference. Singh (2003) stressed that blended learning offers more benefits and is more effective than traditional e-learning. However, studies have shown that academicians are apprehensive about teaching in blended learning (Brooks, 2008).

Okaz (2015) discusses what blended learning is, its pros and cons, and finally provides some hands on experience and classroom activities to help instructors integrate blended learning in higher education. Garrison and Kanuka (2004) suggest that blended teaching can facilitate independent and collaborative learning experiences. Blended learning builds both a community of inquiry and a platform for free and interactive dialogue. In addition, Paechter and Maier (2010) refer to how university students speak in favor of blended learning. Students being digitally literate enhance the chances of extending their lessons and conversations beyond the classroom (Kasraie \& Alahmed, 2014).

Sanja I. Bauk (2015) The scope of this experimental research work is to show how two quantitative methods can be applied in assessing students' perceptions when it comes to e-learning system features: one method when the already existing systems are in question (Saaty's AHP), and the other when it comes to expressing students' wishes or opinions regarding an ideal system to be developed in the future (Kano's model).Popa and Bochis (2015) intended to measure the level of satisfaction of the undergraduate students from the blended weekend classes (BWC) in relation to the academic courses they take. We think that student satisfaction is influenced by their attitude regarding the quality of the textbooks, on one hand, and by the quality of face-to-face activities, on the other hand. The method we used was linear regression with mix purpose: explicit and predictive. Nazarenko (2015) this paper presents a case study research based on the experience of implementing a blended learning approach to a university lecture course for students of FLT methodology at the Faculty of Foreign Languages and Area Studies at Moscow State University. Experimenting with blended learning on a local scale enabled the developers of the course to get an idea of their Students' subjective response to the challenges of new arrangements of their study.

\section{Methodology}

Participants in the study were students in bachelor and master degree of the University of Jordan, of the 2017-18 academic years. A random sample of 250 students within the range of (18-35) years, the original sample on which the study tools were applied consisted of 210 as shown in table 1.

Table 1. Distribution the Participants of the study

Demographic Variables $\quad$ Number of students $\quad$ Percentage




\begin{tabular}{llll}
\hline Gender & Male & 41 & $41 \%$ \\
Fge & Female & 59 & $59 \%$ \\
& $18-21$ & 157 & $62.8 \%$ \\
& $21-26$ & 53 & $21.2 \%$ \\
& $26-29$ & 19 & $7.6 \%$ \\
Qualification & Above 29 & 21 & $8.4 \%$ \\
& Bachelor & 188 & $75.2 \%$ \\
& Master degree & 43 & $17.2 \%$ \\
& PhD & 19 & $7.6 \%$ \\
\hline
\end{tabular}

Table 1 shows the demographic characteristics of the Participants. It can be observed from the table that59 participants of the Sample were females and 41 were males. $62.8 \%$ of the participants were between 18 and 21 years, and $21.2 \%$ were between 21 and 26 years, $15 \%$ were above the age of 26 years. About $75.2 \%$ of the sample in Bachelor degree, 17.2\% in Master degree and 7.6\% study PhD level.

\subsection{Data Collection and Analysis Method}

The method for collecting data was using google form online questionnaire. The questionnaire was tested with the participation of 25 students as a pilot study that helped modify, eliminate flaws and ensure the reliability of the questionnaire. 250 questionnaires were filled by the participants of graduate and undergraduate students. Students who filled the questionnaire received clarifications about filling out the questionnaire; questionnaires were filled during blended learning class in the university computer labs for students who are enrolled in blended learning courses. The results of the questionnaire were analyzed using SPSS program, for the final result and conclusions. According to Chisnall (1997) the non-response is a critical limitation of a research, and in order to reduce a nonresponse rate, the researcher s were available at the time of disseminating the online questionnaire to the sample and the student have filled the online questionnaire

The accuracy of the questionnaire was confirmed using Cronbach's Alpha (Sekaran, 2003). The value of the questionnaire when using SPSS was 0.78 , which indicates a high level internal consistency for the scale. According to Cronbach's Alpha A value with more than 0.7 means a good consistency, the reliability in the $70 \%$ range is acceptable and those who were over $80 \%$ were good (Sekaran, 2003).

The questionnaire was reviewed by the researchers at the King Abdullah II School of Information Technology and school of educational Sciences at Jordan University. The statements in the questionnaire were divided into the following three categories: paragraphs 1-12 - for determining student attitudes toward blended English language instruction; points 13-24 - to determine the negative attitudes and impressions of students from blended learning; paragraphs 25-36 - related to the definition of students' understanding and ideas about mixed learning.. After collected the data from the sample of the study, SPSS v.20 was used for data analysis statically, reliability analysis and mean and standard deviation were applied in statistical analysis.

\section{Results and its Discussion}

The results indicated that all of the student have good experiment about blended learning since they have one or more blended learning 94.2 got instructions, guides or training about using el learning platform used in you blended learning course, a variety of devices are used to get to the online material and the major used devices arranged are University desktop computers, then Mobile devices and laptops.

Table 2. General information about participants

\begin{tabular}{lll}
\hline do you have internet connection outside the university campus & Yes & $100 \%$
\end{tabular}




\begin{tabular}{lll}
\hline & No & $0 \%$ \\
do you have internet connection outside the university campus & Yes & $100 \%$ \\
& No & $0 \%$ \\
Which device you use to get to online educational material used for & Laptop & $65 \%$ \\
e-learning (you can chose more than one device) & University desktop computers & $100 \%$ \\
& Desktop Personal computer & $30 \%$ \\
& Mobile & $88 \%$ \\
How many blended courses you have taken & Tablate & $12.3 \%$ \\
& 2 & $75.2 \%$ \\
Did you receive instructions , guides or training about using el & 3 & $17.2 \%$ \\
learning platform used in you blended learning course & 4 or more & $7.6 \%$ \\
\hline
\end{tabular}

As can be seen from table 2 all of the students have internet connection outside the university campus this because of the good internet services and suitable prices and the spread of smart mobile devices with internet connections that is available for students in Jordan. However the answer to the question of whether if students received instructions, guides or training about using el learning platform used in you blended learning course has been answered positively by $94.2 \%$ of the participants.

Table 3. Attitudes of students toward blended learning

\begin{tabular}{lll}
\hline Statement & yes & \multicolumn{1}{c}{ No } \\
\hline 1. Combination of an online class learning and traditional in- class learning is more effective & $85.4 \%$ & $14.6 \%$ \\
than using one-way delivery of information. & & \\
3. With blended learning the information is obtained by more than one way & $83.6 \%$ & $16.4 \%$ \\
2. Blended learning assignments give me opportunity to read and learn more & $88.2 \%$ & $12.8 \%$ \\
4. Blended learning improves my learning skills & $87.3 \%$ & $12.7 \%$ \\
5. Blended learning enables a student to become more involved in the learning process. & $83.4 \%$ & $16.6 \%$ \\
6. Blended learning involves joint participation and work & $84.1 \%$ & $15.9 \%$ \\
7. A course designed for blended learning useful and interesting & $89.6 \%$ & $10.4 \%$ \\
8. blended learning reinforces interaction between teacher and students & $78.6 \%$ & $21.4 \%$ \\
9. Tasks in the blended learning are understandable & $80.3 \%$ & $21.7 \%$ \\
10. blended learning provides me enough time for performing tasks & $79.7 \%$ & $20.3 \%$ \\
11. I can always get course knowledge from online resources used with blended learning e- & $91.3 \%$ & $8.7 \%$ \\
learning platform & & \\
12. Blended learning sessions are more meaningful because after face to face learning they & $82.1 \%$ & $17.9 \%$ \\
include discussion in online learning environment. & & \\
13. With Blended learning you can control how fast or slow you move through lessons & $72.6 \%$ & $27.4 \%$ \\
\hline
\end{tabular}

Results in table 3 showed that highly percentage of $85.4 \%$ of the respondent see that blended learning which combine online class learning and traditional in- class learning is more effective than using one-way delivery of information The results of this study also indicate that there are statistically $83.6 \%$ see that With blended learning the information is obtained by more than one way. Result showedthat large percentage of $88.2 \%$ believe that Blended learning assignments give them opportunity to read and learn more, $87.3 \%$ Blended learning improves their learning skills. The percentage of the respondent about if Blended learning enables a student to become more 
involved in the learning process was $61.7 \%$ and the major percentage of $84.1 \%$ see that Blended learning involves joint participation and work. The majority of the respondent agreed that a course designed for blended learning useful and interesting. The results also show that blended learning reinforces interaction between teacher and studentswith percentage of $78.6 \%$. However, regarding Tasks in the blended learning are understandable and blended learning provides them with enough time for performing tasks the percent of respondent to these points was $80.3 \%$ and $79.7 \%$ respectively. The majority of respondent see that with blended learning they can always get course knowledge from online resourcesused with blended learning e-learning platform. The percentage of $82.1 \%$ of the respondent see that Blended learning sessions are more meaningful because after face to face learning they include discussion in online learning environment and $72.6 \%$ see that With Blended learning they can control how fast or slow you move through lessons

Table 4. Identify students' negative attitudes towards blended learning

\begin{tabular}{|c|c|c|}
\hline Statement & Yes & No \\
\hline $\begin{array}{l}\text { 13. Low speed internet and connectivity problems causes to reach difficulties with blended } \\
\text { learning online resources }\end{array}$ & $36.1 \%$ & $63.9 \%$ \\
\hline 14. difficulties to use eLearning platform that is used in blended learning & $54.3 \%$ & $45.7 \%$ \\
\hline 15. Materials in the blended learning platform is not good organized & $12.5 \%$ & $87.5 \%$ \\
\hline $\begin{array}{l}\text { 16. The instructor does not have time provide feedback on time when doing interactive } \\
\text { students assignments }\end{array}$ & $13.4 \%$ & $86.6 \%$ \\
\hline 17. blended learning is incomprehensible & $17.1 \%$ & $82.9 \%$ \\
\hline 20. Assignment instructions in blended learning mode hard to follow & $24.4 \%$ & $75.6 \%$ \\
\hline 21. I consider the blended learning challenging & $62.4 \%$ & $37.6 \%$ \\
\hline 22. blended learning contributes to my social isolation & $70.8 \%$ & $29.2 \%$ \\
\hline $\begin{array}{l}\text { 23. In blended learning i need more time for communication with instructor than in } \\
\text { classroom }\end{array}$ & $71.9 \%$ & $28.1 \%$ \\
\hline 24. blended learning brings less knowledge than learning in the classroom & $8.3 \%$ & $91.7 \%$ \\
\hline
\end{tabular}

It can be observed from table 3 that $36.1 \%$ of the Sample finds that Low speed internet and connectivity problems causes to reach difficulties with blended learning online resources. There is also a difficulty to use eLearning platform that is used in blended learning with percentage of 54.3\%

Some of the responses indicated that Materials in the blended learning platform is not good organized. And $13.4 \%$ see that the instructor does not have time provide feedback on time when doing interactive students assignments. The results showed good rate from the respondent whose that Assignment instructions in blended learning mode are easy to follow with percentage of $75.6 \%$; furthermore, the results showed that blended learning challenging with percentage of $62.4 \%$.

Most sample results showed that $71.9 \%$ of respondent see that in blended learning student need more time for communication with instructor than in classroom. However few percentages of $8.3 \%$ of the respondent see that blended learning brings more knowledge than learning in the classroom with percent of $8.3 \%$.

Table 5. Understanding the need for blended learning

\begin{tabular}{lll}
\hline Statment & Yes & No \\
\hline 25. Online video, audio, discussion forms and electronic materialhelped me in the learning & $90.4 \%$ & $9.6 \%$ \\
process with blended learning & & \\
26. Registration of materials for blended learning is attractive & $88.9 \%$ & $11.1 \%$ \\
27. Blended learning it seems to me more comfortable than traditional training & $82.2 \%$ & $17.8 \%$ \\
28. Blended learning gives us deeper information of the subject & $81.6 \%$ & $18.4 \%$ \\
29. My mobile devices (mobile, tablet) help me in learning & $79.3 \%$ & $20.7 \%$
\end{tabular}




\section{Social networks (Facebook, Twitter, etc.) help me in learning}

31. blended mode learning boosted my motivation to achieve of success

32. We need to be trained. how to work in blended learning

33. My course is blended learning helped me get more information

34. Blended learning allows me to use different computer programs

35. Blended learning makes me better understandthe educational material
$61.1 \%$
$38.9 \%$
$86.8 \% \quad 13.2 \%$
$71.7 \% \quad 28.3 \%$
$84.2 \% \quad 15.8 \%$
$83.9 \% \quad 16.1 \%$
$85.7 \% \quad 14.3 \%$

Table 5 results showed that the majority of respondent agree that online video, audio, discussion forms and electronic material helped me in the learning process with blended learning. The percentages of $88.9 \%$ of respondent see that Registration of materials for blended learning is attractive. The results also shows high rate from resonant of $82.2 \%$ who believe that Blended learning it seems to me more comfortable than traditional training and it give them deeper information of the subject with percentage of $81.6 \%$.A percentage of $79.3 \%$ see that their mobile devices (mobile, tablet) help them in learning. Some of the respondents see that social networks (Facebook, Twitter, etc.) help them in learning with percentage of $61.1 \%$. However the majority have shown that blended mode learning boosted their motivation to achieve of success and helped them get more information with percentage of $86.8 \%$ and $84.2 \%$ respectively. However $71.7 \%$ of respondent see that they need to get training about blended learning. Further, $83.9 \%$ agreed that blended learning allowed them to use different computer programs the results also shows $85.7 \%$ agreed that blended learning makes them understand the educational material better.

\section{Discussion}

The purpose of this study was to explore Jordanian University students' the attitude of students toward blended learning with understanding of their needs for blended learning. The results of the study indicated that students had positive attitude about blended learning. And they prefer blended and the they believe that the Combination of online class learning and traditional in- class learning is more effective than using one-way delivery of information

Answers to the first section of the questioner, which determines the attitude of students toward blended learning revealed that most students expressed positive attitude to this type of learning, which confirms opinions of many researchers. Despite this It is quite natural that there are few students who have expressed their dissatisfaction with participation in the blended learning process. Overall, the results show student satisfaction with the application blended learning as it improved their learning skills and made the learning process collaborative, interactive and interesting. It was also confirmed that it promotes interaction between the teacher and students outside classes and gives students more time to complete tasks.

The third section of questions, data on the answers to which are presented in Table 3, associated with the identification of negative attitudes of students towards blended learning. A quick look at the results in the table makes it clear that there are some negative impressions of students from the process of learning using blended learning. Among the noted disadvantages of blended learning were low Internet connection speed; difficulties to use model that is used in blended learning. Network and lack of live communication. Some students find it difficult to use electronic resources, the amount of knowledge gained is not low, but there is a lack of practice, skills and training instructions for use. Among the minuses is also social isolation, not good organization of materials. Also students need more time to communicate, student motivation cheating and other unethical practices of behavior. Among the main drawbacks is a great investment of time, since communication through forums, mail require more time than live communication in the classroom

Table 4 presents the results of respondent to questions related to determining their understanding of the need for blended learning. Students noted that electronic resources such as online video, audio, discussion forms and electronic material help them learn better. And this makes them think about the need to study more deeply. Students find the course materials attractive. The use of various computer programs, the use of personal mobile devices (mobile, tablet, laptop), and the possibility of obtaining more information from electronic e-learning platform leads them to self-development and motivates success

\section{Conclusion}

This study showed that student have positive attitude towered blended learning. it also indicate that blended learning which combine online class learning and traditional in- class learning is more effective than using traditional learning process. it also show that with blended learning the information is obtained by more than one 
way. Students believed that blended learning assignments give them opportunity to read and learn more. Furthermore, the results of the study indicated that blended learning is useful to students, and that most students fully understand the goals of e-learning through blended learning. In general the students have shown positive attitude towered blended learning. However, they have shown adequate information about the field of blended learning and to decide when and how to use the resources provided to them through blended learning. Therefore, the study recommends further research to explore the differences between different teaching approaches that use information technology including e-learning, distant learning and blended learning; additional areas of research should be considered is to understand how attitudes toward blended learning related to some variables like age, gender, disabilities if the learner have such as blindness and hearing disabilities.

\section{References}

Abeer, A. O. (2015). Integrating Blended Learning in Higher Education. Procedia - Social and Behavioral Sciences, 186, 600-603.

Abelsson, A., Rystedt, I., Suserud, B. O., \& Lindwall, L. (2016). Learning by simulation in prehospital emergency care - an integrative literature review. Scand. J. Caring Sci., 30(2), 234-240. https://doi.org/10.1111/scs. 12252

Alshehri, F. (2017). Student satisfaction and commitment towards a blended learning finance course: A new evidence from using the investment model. International Business and Finance, 41, 423-433.

Behnke, C. (2011). Blended learning in the culinary arts: tradition meets technology. In: Glazier, F. (Ed.), New Pedagogies and Practices for Teaching in Higher Education: Blended Learning: Across the Disciplines, Across the Academy. Stylus, Sterling, VA, pp. 13-30.

Brinkert, R. (2010). A literature review of conflict communication causes, costs, benefits and interventions in nursing. J. Nurs. Manag. 18, 145-156.

Brooks, L. (2008). An Analysis of Factors that affect faculty attitudes toward a blended learning environment", Ph.D dissertation, Faculty of the College of Education, TUI University, California, 2008.

Bunyarit, M. (2006). E-learning Systems: An Evaluation of Its Effectiveness In Selected Higher Learning Institutions in Malaysia. M.S thesis, International Islamic University Malaysia.

Carver, N., Ashmore, R., \& Clibbens, N. (2007). Group clinical supervision in pre-registration nurse training: the views of mental health nursing students. Nurse Educ. Today, 27(1), 768-776.

Clark, R. C., \& Mayer, R. E. (2003). E-learning and the Science of Instruction. Jossey -Bass, San Francisco.

Dearnley, C., McClelland, G., \& Irving, D. (2013). Innovation in Teaching and Learning in Health Higher Education. The Higher Education Academy, London.

Elisabeth, C., Hazel, R., Valda, F., Victoria, K., Melanie, P., Marion, M. (2018). Nurse Education Today, 63(2018) 101-107, Investigation of blended learning video resources to teach health students clinical skills: An integrative review.

Ersoy, H. (2003). BirÇevrimiçiÖrenim Destek Sisteminin Kullanılabilirlik Testi: Planlama, Uygulama, Deerlendirme. Paper presented at International Educational Technologies Symposium and Fair. GaziMausa, Turkish Republic of Northern Cyprus.

Foronda, C., MacWilliams, B., \& McArthur, E. (2016). Interprofessional communication in healthcare: an integrative review. Nurse Educ. Pract., 19, 36-40.

Garrison, D. R., \& Kanuka, H. (2004). Blended learning: Uncovering its transformative potential in higher education. The Internet and Higher Education, 7, 95-105.

Graham, C. R. (2006). Blended learning systems. Definition, current trends, and future directions. Handbook of Blended Learning: Global Perspectives, Local Designs, 3-21.

Ha, J. F., \& Longnecker, N. (2010). Doctor-patient communication: A review. Ochsner J., 10(1), 38-43.

Haryani, H., \& Rose, A. A. (2009). An Interpretive Tacit Knowledge Exploration of Malaysian Academicians.Unpublished Thesis, University Technology Malaysia.

Haryani, H., Wan, F. A., \& Nor, A. R. (2012). The Adoption of Blended Learning among Malaysian Academicians. Procedia - Social and Behavioral Sciences, 67, $175-181$

Haskard, Z. K. B., \& DiMatteo, M. R. (2009). Physician communication and patient adherence to treatment: a meta-analysis. Med. Care, 47(8), 826-834. 
Hien, M. V., Chang, Z., \& Nguyet, A. D. (2017). The effect of blended learning on student performance at courselevel in higher education: A meta-analysis, Elsevier Ltd. All rights reserved.

Karen, M. C., Peter, O., \& Maria, L. (2018). Online learning versus blended learning of clinical supervisee skills with pre-registration nursing students: A randomised controlled trial. International Journal of Nursing Studies.

Kasraie, N., \& Alahmad, A. (2014). Investigating the reasons institutions of higher education in the USA and Canada utilize blended learning. Mevlana International Journal of Education (MIJE), 4(1), 67-81, 1 April, 2014. https://doi.org/10.13054/mije.13.68.4.1

Khazaei, S., \& Dastjerdi, H. V. (2011). An Investigation into the Impact of Traditional vs. Blended Teaching on EFL Learners' Vocabulary Acquisition: M-learning in Focus. International Journal of Humanities and Social Science, 1(15), 202-207

Kourkouta, L., \& Papathanasiou, I. V. (2014). Communication in nursing practice. Mater. Soc.-Med. 26 (1), 65.

Masrom, M., et al. (2008). Critical Success in E-Learning: An Examination of Technological and Institutional Support Factors. International Journal of Cyber Society and Education, 1(2), 131-142.

McCabe, C., \& Timmins, F. (2014). Communication Skills for Nursing Practice. Palgrave Macmillan, London.

McCutcheon, K., Lohan, M., Traynor, M., \& Martin, D. (2015). A systematic review evaluating the impact of online or blended learning versus face-to-face learning of clinical skills in undergraduate nurse education. $J$. Adv. Nurs., 71(2), 255-270.

Nazarenko, A. L. (2015). Blended learning vs traditional learning: What works?(A case study research). ProcediaSocial and Behavioral Sciences, 200, 77-82.

Paechter, M., \& Maier, B. (2010). Online or face-to-face? Students' experiences and preferences in e-learning. Internet and Higher Education, 13, 292-297.

Pazio, M. (2010). Blended learning and its potential in expanding vocabulary knowledge: A case study. Teaching English with Technology, 10(1), 3-30.

Sanja, I. B. (2015). Assessing Students' Perception of E-Learning In Blended Environment: An Experimental Study. Procedia - Social and Behavioral Sciences, 191, 323-329.

Schmid, R. F., Bernard, R. M., Borokhovski, E., Tamim, R. M., Abrami, P. C., Surkes, M. A., ... Woods, J. (2014). The effects of technology use in postsecondary education: A meta-analysis of classroom applications. Computers and Education, 72, 271-291. https://doi.org/10.1016/j.compedu.2013.11.002

Schmidt, E., \&Hegelheimer, V. (2004). Effects of Online Academic Lectures on ESL Listening Comprehension, Incidental Vocabulary Acquisition, and Strategy Use. Computer Assisted Language Learning, 17(5), 525-564.

Sezen, T. Procedia - Social and Behavioral Sciences 199 (2015), 641-647, The effects of blended learning on EFL students' vocabulary enhancement

Shefaly, S., Yanika, K. M., Kamala, D., Chen, H. C., Swee, K. A. S., \& Emily, A. (2018). Blended learning pedagogy designed for communication module among undergraduate nursing students: A quasi-experimental study. Nurse Education Today, 61, 120-126,

Singh, H. (2003). Building Effective Blended Learning Programs. Educational Technology, 43(6), 51-54.

Smart, K. L., \& Cappel, J. J. (2006). Students' perceptions of online learning: A comparative study. J. Inf. Technol. Educ., 5, 201-219.

Staun, M., Bergstrom, B., \& Wadensten, B. (2010). Evaluation of a PBL strategy in clinical supervision of nursing students: patient-centred training in student-dedicated treatment rooms. Nurse Educ. Today, 30(1), 631-637.

Vessey, J. A., DeMarco, R., \& DeFazio, R. (2010). Bullying, harassment, and horizontal violence in the nursing workforce. Annu. Rev. Nurs. Res., 28(1), 133-157.

Yeonja, C., Eunju, S., \& Eunjung, O. (2015). Effects of teaching communication skills using a video clip on a smart phone on communication competence and emotional intelligence in nursing students. Arch. Psychiatr. Nurs., 29(2), 90-95. https://doi.org/10.1016/j.apnu.2014.11.003.(96p)

\section{Copyrights}

Copyright for this article is retained by the author(s), with first publication rights granted to the journal. 
This is an open-access article distributed under the terms and conditions of the Creative Commons Attribution license (http://creativecommons.org/licenses/by/4.0/). 